\title{
Avaliação da expressão do gene MGMT nos tecidos normal e neoplásico de doentes com câncer colorretal
}

\section{Evaluation of the expression of the MGMT gene in normal and neoplastic tissue of patients with colorectal cancer}

Adriana Teixeira Cordeiro"; Camila Morais Gonçalves da Silva²; Waldemar Bartchewsky Júnior 3 ; Marcelo Lima Ribeiro4; Carlos Augusto Real Martinez, TCBC-SP5

\author{
R E S U M O
}

\begin{abstract}
Objetivo: Avaliar a expressão tecidual do gene de reparo MGMT comparando a mucosa cólica normal e neoplásica em doentes com câncer colorretal. Métodos: Foram estudados 44 portadores de adenocarcinoma colorretal confirmado por estudo histopatológico. Foram excluídos doentes suspeitos de pertencerem a famílias com câncer colorretal hereditário (HNPCC e PAF) e oS portadores de câncer do reto médio e inferior submetidos a tratamento quimioradioterápico neoadjuvante. A expressão do gene MGMT foi avaliada pela técnica da reação de polimerase em cadeia em tempo real (RT-PCR). A comparação dos resultados encontrados para expressão do gene MGMT entre tecidos normais e neoplásicos foi feita pelo teste t de Student pareado, adotando-se nível de significância de $5 \%(p<0,05)$. Resultados: A expressão tecidual do gene MGMT em todos os doentes foi menor no tecido neoplásico quando comparada a do tecido normal ( $p=0,002$ ). Conclusão: $O$ gene de reparo MGMT encontra-se menos expresso no tecido neoplásico quando comparados aos tecidos normais em portadores de CCR esporádico.
\end{abstract}

Descritores: Neoplasias Colorretais. Alquilantes. Reparo do DNA. O(6)-metilguanina-DNA metiltransferase. Reação em cadeia da polimerase.

\section{INTRODUÇÃO}

O desenvolvimento do câncer colorretal (CCR) é um processo sequencial, que envolve acúmulo progressivo de mutações que resultam na ativação de oncogenes e inativação de genes supressores de tumor. O conhecimento dos eventos genéticos e epigenéticos envolvidos na carcinogênese colorretal é importante tanto para a melhor compreensão dos mecanismos responsáveis pela transformação maligna das células normais, quanto para o desenvolvimento de novas estratégias terapêuticas ${ }^{1}$.

O epitélio cólico encontra-se constantemente exposto aos radicais livres de oxigênio, nitrogênio e metil $\left(\mathrm{CH}_{3}\right)$, produzidos durante o metabolismo das próprias células epiteliais ou oriundos do meio externo. Para protegêlas contra o dano provocado por esses radicais, as células da mucosa cólica contam com eficientes mecanismos de reparo, representados, principalmente pelos sistemas BER (Base Excision Repair), NER (Nucleotide Excision Repair) e MMR (MisMatch Repair)². O gene MGMT(OMIN: 156569), também conhecido como AGT e AGAT, um dos componentes do sistema de reparo do DNA, codifica a $0^{6}$ metilguanina-DNA metiltransferase (MGMT), uma das mais importantes proteínas de reparo do DNA, específica para correção da incorporação de radicais $\mathrm{CH}_{3}$ na base guanina que leva a formação da base metilada $\mathrm{O}^{6}$-metilguanina. A remoção do radical $\mathrm{CH}_{3}$ da molécula da $\mathrm{O}^{6}$-metilguanina tem fundamental importância para evitar mutações ocasionadas por transições de bases decorrentes da presença da base metilada.

Estudos mostraram que o acúmulo de mutações no CCR esporádico pode estar relacionado à redução da expressão tecidual do gene $M G M T^{1,3,4}$. Como consequência, a menor transcrição da proteína MGMT reduz a capacidade de correção dos erros de pareamento de bases decorrentes da hipermetilação. A menor capacidade de reparo aumenta a possibilidade de surgirem mutações capazes de formarem clones de células com autonomia proliferativa e resistência a apoptose principais características das células neoplásicas.

Trabalho realizado no Programa de Pós-Graduação em Ciências da Saúde da Universidade São Francisco, Bragança Paulista, São Paulo. 1. Acadêmica do Curso de Medicina da Universidade São Francisco, Bragança Paulista, (SP). Bolsista e Iniciação Científica (FAPESP); 2. Mestranda do Programa de Pós-Graduação em Ciências da Saúde da Universidade São Francisco, Bragança Paulista, (SP). Bolsista CAPES; 3. Pós-Graduando em Farmacologia da Universidade Estadual de Campinas, SP; 4. Professor Assistente do Programa de Pós-Graduação em Ciências da Saúde da Universidade São Francisco, Bragança Paulista, (SP); 5. Professor Livre-Docente pelo Departamento de Cirurgia da Faculdade de Medicina da Universidade de São Paulo. Professor Adjunto do Programa de Pós-Graduação em Ciências da Saúde da Universidade São Francisco, Bragança Paulista, (SP). 
A utilização de substâncias com poder alquilante (capazes de transferir radicais $\mathrm{CH}_{3}$ para bases do DNA) para induzir a apoptose das células neoplásicas, é uma das estratégias mais antigas empregadas para o tratamento quimioterápico do CCR ${ }^{5}$. Essas drogas incorporam radicais $\mathrm{CH}_{3}$ na base guanina, formando grandes quantidades de $\mathrm{O}^{6}$-metilguanina que por exceder a capacidade dos sistemas de reparo do DNA, induz a apoptose celular $r^{6,7,8}$. Essa possibilidade ficou mais evidente quando se demonstrou que o aumento do conteúdo tecidual da proteína MGMT, pela maior remoção da guanina oxidada, encontrava-se relacionado a menor resposta terapêutica aos tratamento quimioterápico ${ }^{8}$. De modo inverso, a associação de substâncias que inibem a proteína MGMT aumentaram, significativamente a resposta a essas drogas.

É possível que a importância da expressão tecidual do gene MGMT na resposta aos quimioterápicos possa estar relacionada ao papel desempenhado pelos genes de reparo no ciclo celular. Durante a mitose caso exista erro no pareamento de bases, a célula pode seguir dois caminhos distintos. Quando o erro é reconhecido e reparado, a divisão celular segue seu curso natural assegurando que o DNA da nova célula formada não tenha sofrido mutações. Entretanto, quando o erro de pareamento não pode ser reparado, para evitar o aparecimento de mutações nas futuras gerações de células, ocorre indução da apoptose por proteínas específicas, que formam a última estratégia de defesa contra a formação de células mutantes. Agentes quimioterápicos, como a mostarda nitrogenada, ciclofosfamida, dacarbazina agem formando grandes quantidades de bases metiladas, que ultrapassando a capacidade de correção pelo sistema de reparo, induzem a apoptose celular. Esses achados sugerem que o conhecimento prévio da expressão tecidual do gene MGMT em portadores de CCR poderia ser considerada uma estratégia útil para separar os doentes que se beneficiariam ou não da quimioterapia adjuvante melhorando a relação custo benefício do tratamento9. Todavia, torna-se necessário, inicialmente avaliar se a expressão tecidual do gene MGMT no tecido neoplásico encontra-se reduzida nos portadores de $C C R$, em relação à dos tecidos normais. A expressão do gene MGMT comparando tecidos normais e neoplásicos até o momento foi pouco avaliada, o que motivou a elaboração do presente estudo.

\section{MÉTODOS}

O presente estudo recebeu aprovação do Comitê de Ética em Pesquisa da Universidade São Francisco (Projeto $n^{\circ}$ : 0235.0.142.000-07). Todos os pacientes que forneceram material biológico para a pesquisa assinaram o Termo de Consentimento Livre e Esclarecido após serem informados de todas as etapas experimentais.

Foram selecionados para o presente estudo 44 enfermos (22 mulheres), com média de idade de 62,4 anos, portadores de adenocarcinoma do cólon e reto superior, submetidos a tratamento cirúrgico com intenção curativa, por uma mesma equipe cirúrgica entre janeiro de 2007 e dezembro de 2008. Foram excluídos os suspeitos de pertencerem à famílias com CCR hereditário (polipose adenomatosa familiar e câncer colorretal hereditário não polipoide), portadores de CCR associado à doença inflamatória intestinal, os operados em caráter de urgência e os portadores de câncer do reto médio e inferior por terem sido submetidos a tratamento radioquimioterápico neoadjuvante.

Imediatamente após a remoção do espécime cirúrgico, foram retirados três fragmentos da mucosa cólica normal distante no mínimo de $10 \mathrm{~cm}$ da margem superior da neoplasia. Da mesma forma, foram coletados três fragmentos da mucosa neoplásica, sempre obtidos da periferia do tumor. Os fragmentos removidos foram identificados, acondicionados, individualmente em recipientes apropriados, e imediatamente enviados ao Laboratório de Biologia Molecular da Universidade São Francisco, onde foram resfriados $a-80^{\circ} \mathrm{C}$, até o momento da realização dos ensaios experimentais. Os três fragmentos de cada tecido foram destinados ao estudo da expressão do gene MGMT pela reação em cadeia de polimerase em tempo real (RT-PCR). A amplificação do gene MGMT por RT-PCR foi realizada sempre pelo mesmo técnico, em bateria única e em triplicata. O diagnóstico histológico de adenocarcinoma colorretal foi confirmado por patologista experiente em neoplasias colorretais, que desconhecia os objetivos do presente estudo.

Para a avaliação da expressão dos genes MGMT e do gene constitutivo $b$-actina a extração do RNA foi realizada nos três fragmentos obtidos da mucosa cólica normal e nos três da neoplásica. Para a estabilização e proteção do RNA, após a ressecção cirúrgica todas as amostras foram acondicionadas em frascos contendo RNA-later (QIAGEN, Valencia, CA, USA) e refrigeradas à $-80^{\circ} \mathrm{C}$ até o momento da extração do RNA. A extração do RNA foi feita com o emprego do $R N$-easy ${ }^{\circledR}$ tissue kit (QIAGEN), seguindo o protocolo do fabricante. Após a extração, aproximadamente $100 \mathrm{mg}$ de RNA foram utilizadas para a síntese do cDNA usando o high capacity cDNA archive kit (Applied Biosystems, Foster City, CA, USA).

A análise da expressão dos genes MGMT e do gene constitutivo â-actina foi feita por RT-PCR utilizando o equipamento iCycler IQTM (Bio-Rad, USA). Os experimentos foram sempre feitos em triplicata, e as amostras foram normalizadas usando-se um dos controles constitutivos. A tabela 1 mostra os primers utilizados para a amplificação dos genes $M G M T$ e $\beta$-actin. A expressão relativa de ambos os genes estudados foi calculada de acordo com fórmula $2^{\text {(Rt-Et)/2(Rn-En) }}$ previamente descrita ${ }^{10}$. O valor final adotado para a expressão dos genes de reparo MGMT e do gene constitutivo â-actina foi o valor médio encontrado nos três fragmentos analisados de cada doente. 
Tabela 1 - Primers utilizados para amplificação dos genes MGMT e $\beta$-actina.

\begin{tabular}{lll}
\hline Gene & Primer & Sequência $\left(\mathbf{5}^{\prime} \rightarrow \mathbf{3} \mathbf{3}^{\prime}\right)$ \\
\hline MGMT & MGMT-sense & CGAACTTGCCCAGGAGCTTTATTT[FAM]G \\
& MGMT-antisense & CACCACACTGGACAGCCCTTT \\
$\boldsymbol{\beta}$-actina & $\beta$-actin-sense & CGGCTAATACACACTCCAAGGC[FAM]G \\
& $\beta$-actin-antisense & ACACTGGCTCGTGGACAAGG \\
\hline
\end{tabular}

Os resultados obtidos para a expressão do gene MGMTforam expressos segundo o valor médio com o respectivo erro padrão considerando os tecidos normais e neoplásicos. Empregou-se o teste t de Student pareado na comparação entre os valores adotando-se intervalo de confiança de 95\%. Estabeleceu-se nível de significância de $5 \%(p<0,05)$. Todos os dados obtidos foram analisados usando o programa estatístico SPSS 13.0 (SPSS Inc., Chicago, USA).

\section{RESULTADOS}

A figura 1 mostra os resultados obtidos com a amplificação do gene MGMT, comparando o tecido normal e o neoplásico. Verificou-se que, no tecido normal, os valores encontrados para amplificação do gene foi 0,1974 $\pm 0,02 \cup A$, enquanto que no neoplásico foi 0,1100 $\pm 0,01 \cup A$.

A tabela 2 mostra os valores médios, com o respectivo erro padrão e intervalo de confiança dos valores

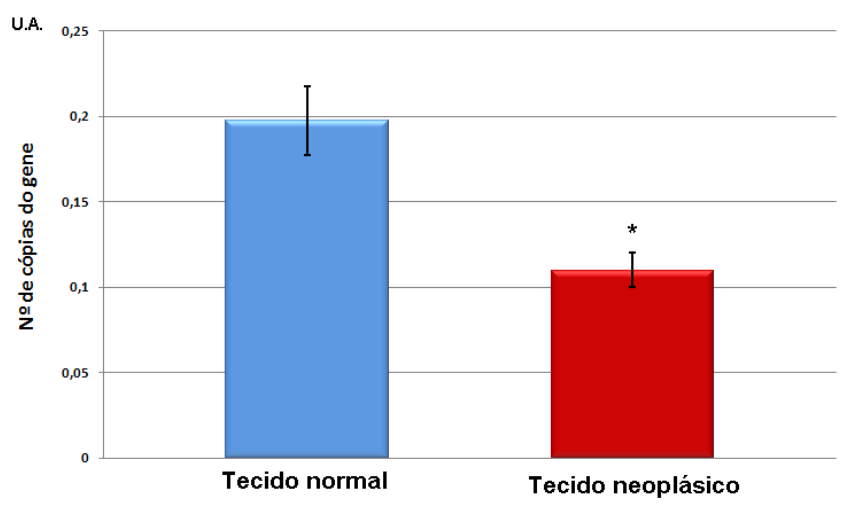

Figura 1 - Média com o respectivo erro padrão do número de cópias amplificadas do gene MGMT, comparando os tecidos normal e neoplásico.

U.A. = Unidades arbitrárias; * = significante; Teste t pareado. encontrados comparando a expressão do gene MGMT nos tecidos normal e neoplásico. Verificou-se que no tecido normal a expressão do gene MGMT foi significativamente maior quando comparada a do tecido neoplásico $(p=0,002)$.

\section{DISCUSSÃO}

Na carcinogênese colorretal existem duas vias distintas e bem definidas, representadas pelas vias de instabilidade cromossômica (CIN) e instabilidade de microssatélites (MSI)11,12. A primeira, também conhecida como via "clássica", parece ser a mais comum e depende de um acúmulo sequencial de mutações em protoncogenes ou genes supressores de tumor. A via CIN frequentemente encontra-se relacionada à deleções de partes importantes dos cromossomos. A via MIS por sua vez, relaciona-se à instabilidade genômica, onde ocorrem mutações em genes do sistema de reparo do DNA, possibilitando acúmulo acelerado de mutações nos genes envolvidos em diversas funções celulares, sobretudo naqueles relacionados ao controle do ciclo celular. A via CIN, geralmente encontra-se associada ao CCR esporádico que obedece a sequência clássica adenoma-carcinoma, enquanto a via MSI ao câncer colorretal heredidário não polipoide (HNPCC) relacionado à deficiências nas proteínas de reparo do DNA. De modo interessante, neoplasias oriundas dessas duas vias carcinogênicas apresentam aspectos histopatológicos distintos, quando se comparam tumores relacionados à instabilidade cromossômica com àqueles decorrentes de MSI.

Apesar da maioria dos tumores colorretais apresentarem fenótipos que se enquadravam nessas duas vias de carcinogênese, estudos mostraram que alguns apresentavam características fenotípicas diferente daquelas encontradas nas duas vias conhecidas ${ }^{13}$. O estudo genético desses tumores mostrou, que existia a incorporação de uma grande quantidade de radicais $\mathrm{CH}_{3}$ nas "ilhas $\mathrm{CpG}$ " $\mathrm{da}$

Tabela 2 - Comparação dos valores da expressão do gene MGMT nas células normais e neoplásicas da mucosa cólica de doentes com câncer colorretal.

\begin{tabular}{cccccc}
\hline & & \multicolumn{3}{c}{ Média \pm EP $($ UA $)$} & \\
\cline { 3 - 4 } & $\mathrm{n}$ & Tecido Normal & Tecido Neoplásico & IC $-95 \%$ & $\mathrm{p}$ \\
\hline MGMT & 44 & $0,1974 \pm 0,02$ & $0,1100 \pm 0,01$ & $0,0324-0,1424$ & $0,002^{*}$ \\
\hline
\end{tabular}

$U A=$ Unidades arbitrárias; $n=$ número de doentes; $E P=$ Erro padrão;/C95\% = intervalo de confiança $(95 \%) ;{ }^{*}=$ significativo; Teste $t$ pareado; 
região promotora dos genes (região 5'). A região 5' contém sequências específicas de bases nitrogenadas que determinam onde deverá iniciar-se o processo de transcrição dos genes, sendo, por isso, conhecidas como região promotora. Caso sofram hipermetilação os fatores de transativação encontram dificuldade para iniciarem o processo de transcrição, tornando o gene menos expresso. As "ilhas CpG" são regiões formadas, fundamentalmente, pelas bases citosina e guanina (geralmente acima de $50 \%$ dos nucleotídeos existentes no local). A base guanina é a base do DNA mais sujeita à metilação. Genes que apresentam menor expressão geralmente tem maior tendência ao aumento da incorporação de radicais $\mathrm{CH}_{3}$ nas bases das "ilhas CpG".

A hipermetilação da região promotora dos genes é uma das alterações epigenéticas atualmente mais estudadas no CCR, pois é capaz de impedir a transcrição de proteínas fundamentais para o controle do ciclo celular. Quando os níveis de metilação são muito altos pode haver, até mesmo, a completa inativação do gene incapacitando-o de traduzir a proteína por ele codificada ${ }^{3,4} \mathrm{~A}$ importância desse mecanismo carcinogênico no CCR tem sido confirmada por estudos demonstrando que a hipermetilação da região promotora do gene de reparo $h M L H 1$, associado ao HNPCC, é encontrada em até $80 \%$ dos casos de CCR, com erros de replicação $(\operatorname{RER}+)^{7,14}$. Esta nova via de carcinogênese asssociada à hipermetilação da região promotora dos genes foi batizada de CIMP (CpG Island Methilated Phenothype). Fenotipicamente os tumores relacionados à via CIMP localizam-se, principalmente, no cólon proximal e, geralmente, apresentam-se associados à $\mathrm{MSI} 8,15$

Estudos experimentais confirmaram a relação entre a metilação e o CCR. O azoximetano, substância carcinogênica frequentemente utilizada em modelos experimentais de CCR, tem como principal mecanismo de ação o aumento na formação da guanina metilada $\left(O^{6}\right.$ metilguanina) ${ }^{1}$. A substância age aumentando a incorporação de radicais $\mathrm{CH}_{3}$ no oxigênio localizado na posição ' 6 ' da molécula da guanina, formando $0^{6}$-metilguanina, considerada a base metilada mais relacionada ao aparecimento de mutações do DNA' .

O gene MGMT, há quase duas décadas, vem sendo relacionado à carcinogênese colorretal 16,17. Localizase no cromossoma '10' na região $10 q 26$, e transcreve a proteína MGMT que age, especificamente, no reparo de moléculas $O^{6}$-metilguanina inapropriadamente pareadas durante a replicação do DNA. A MGMT é uma das poucas proteínas capazes de reparar o DNA danificado por agentes alquilantes. Seu mecanismo de ação não permite que seja considerada como uma enzima verdadeira, por receber o radical $\mathrm{CH}_{3}$ em uma reação estequiométrica, não se regenerando após a metilação ${ }^{18}$. A proteína selvagem remove, continuamente, os radicais $\mathrm{CH}_{3}$ das moléculas de $\mathrm{O}^{6}$-metilguanina produzidos pelo próprio metabolismo celular, ou proveniente do consumo de dietas ricas em gor- duras, carnes vermelhas e tabaco. A proteína também é capaz de remover radicais $\mathrm{CH}_{3}$ fornecidos pelas drogas quimioterápicas alquilantes, interferindo na resposta terapêutica a essas substâncias ${ }^{9}$. Os erros de pareamento durante a replicação do DNA decorrentes da formação da $\mathrm{O}^{6}$-metilguanina surgem em virtude da base metilada parearse com a timina no lugar da citosina, ocasionando transições de base do tipo G:C®AT ${ }^{19}$ Quando o gene MGMT apresenta redução da sua capacidade de expressão, geralmente por hipermetilação da região promotora, a proteína MGMT não será traduzida ${ }^{20}$. A proteína MGMT age transferindo os radicais $\mathrm{CH}_{3}$ removidos da $\mathrm{O}^{6}$-metilguanina, para um sítio receptor e cisteína localizado na estrutura molecular proteína ${ }^{1,21}$. A S-metilcisteína formada no sítio ativo da proteína selvagem, após a agregação do radical $\mathrm{CH}_{3}$, impede que ele seja reconvertido novamente em cisteína, fazendo com que cada molécula da MGMT atue apenas uma única vez, provavelmente por uma alteração conformacional da molécula, pela sua rápida degradação pelo sistema ubiquitina ${ }^{12}$. Como a reação de inativação da MGMT é irreversível, a proteína deve ser constantemente produzida para remover radicais $\mathrm{CH}_{3}$ de outras moléculas de $\mathrm{O}^{6}$-metilguanina. Em outras palavras, as células dependem da síntese contínua da proteína MGMT para remoção dos erros de pareamento. Para que exista tradução contínua da proteína, o gene MGMT não pode estar metilado. Estudos experimentais confirmaram esses fatos ao demonstrarem que ratos transgênicos com maior expressão do gene MGMT e, consequentemente, maior transcrição da proteína, são mais resistentes às mutações do tipo $\mathrm{G}: \mathrm{C} \circledast \mathrm{AT}^{22}$.

A hipermetilação da região promotora do gene MGMT é conhecida há vários anos como uma possível causa para explicar a menor expressão do gene nas células neoplásicas ${ }^{23}$. No tecido neoplásico com a perda da expressão do gene é possível identificar vários genes reguladores que sofreram um significativo índice de mutações do tipo transição G:C®A:T. Já foi demonstrado que, quando o gene MGMT encontra-se menos expresso, ocorre aumento de mutações por transversões de bases tanto em oncogenes, como o K-ras, quanto em genes supressores de tumor como o $p 53^{24-26}$. O acúmulo sequencial de mutações nesses genes é frequentemente encontrado nos doentes com CCR esporádico 24,25,27. Estudos de sequenciamento simultâneo nos dois genes mostraram que a mutação mais comumente identificada em ambos são transversões do tipo G:C®A: $\mathrm{T}^{24,25}$.

Os resultados do presente estudo confirmam que a expressão tecidual do gene MGMT encontra-se reduzida nos tecidos neoplásicos de portadores de CCR esporádico em relação aos tecidos normais. Os achados sugerem que, no tecido neoplásico, exista menor capacidade de reparo de $O^{6}$-metilguanina no DNA, o que aumenta a possibilidade de mutações do tipo transições $\mathrm{G}: C \circledR A: \mathrm{T}^{26}$. De outra forma, a maior expressão do gene nos tecidos normais confirma a importância da produção constante da proteína 
MGMT na prevenção de mutações em células epiteliais cólicas, constantemente expostas aos radicais $\mathrm{CH}_{3}$. A perda dessa capacidade no tecido neoplásico sugere que, em algum momento, a redução do conteúdo celular da proteína MGMT possibilitou uma deficiência no mecanismo de reparo, possibilitando o aparecimento de células mutantes.

Teorias tentam explicar a menor expressão dos genes de reparo no tecido neoplásico dos portadores de CCR esporádico. Uma delas propõe que a metilação da região promotora dos genes de reparo é o principal mecanismo responsável pela sua menor expressão no tecido neoplásico ${ }^{28}$ Outra sugere que o processo de metilação possa ocorrer, simultaneamente nos diferentes sistemas de reparo ${ }^{3,14,15}$. Em estudo anterior, avaliando o mesmo grupo de doentes, verificamos que o gene $h M L H 1$ apresentava menor expressão no tecido neoplásico quando comparado ao tecido normal29. É possível que o gene $h M L H 1$, um dos principais componentes do sistema MMR de reparo do DNA, também estivesse menos expresso em decorrência da hipermetilação da sua região promotora, entretanto, naquela oportunidade, essa possibilidade não foi avaliada. Contudo, estudos anteriores que avaliaram essa possibilidade confirmaram que ocorre menor expressão dos genes de reparo em portadores de CCR esporádico, relacionada ao aumento progressivo da incorporação de radicais $\mathrm{CH}_{3}$ na sua região promoto$\mathrm{ra}^{24,25,26}$

Estudos com maior número de doentes que avaliem, concomitantemente, a presença de transições de base do tipo G:C®A:T em genes relacionados ao controle do ciclo celular, como o k-ras e o p53, e a expressão do MGMT ainda são necessários para melhor compreensão do papel desempenhado pelo gene no desenvolvimento de mutações responsáveis pela quebra da homeostase entre a proliferação celular controlada e a apoptose programada. Apesar de nos últimos anos ter ocorrido aumento exponencial no conhecimento dos eventos epigenéticos relacionados ao gene $M G M T$, pesquisas ainda são necessárias para validar a pesquisa rotineira da expressão do gene MGMT antes da proposição de um determinado esquema quimioterápico. Somente estudos com sequenciamento relacionando eventuais polimorfirmos do gene MGMT, resposta a agentes quimioterápicos e a sobrevida em grandes séries poderá responder esses questionamentos ${ }^{30}$.

Os resultados encontrados no presente estudo mostraram que, no tecido tumoral, existe redução da expressão do gene MGMT, tornando o tecido neoplásico potencialmente sensível a protocolos de quimioterapia que utilizem agentes alquilantes.

\section{A $B$ B S T $R$ R A C $C$}

Objective: To evaluate the expression of tissue repair gene MGMT by comparing normal and neoplastic colonic mucosa in patients with colorectal cancer (CRC). Methods: We studied 44 patients with colorectal cancer confirmed by histopathology. We excluded patients suspected of belonging to families with hereditary colorectal cancer (HNPCC and FAP) and patients with cancer of the lower or medium rectum treated with neoadjuvant chemoradiotherapy. The MGMT gene expression was assessed by the technique of polymerase chain reaction in real time (RT-PCR). The comparison of results for MGMT gene expression between normal and neoplastic tissues was made by paired Student's $t$ test, adopting a significance level of $5 \%(p<0.05)$. Results: Tissue expression of the MGMT gene in all patients was lower in tumor tissue when compared to normal tissue $(p=0.002)$. Conclusion: The repair gene MGMT is less expressed in tumor tissue compared to normal tissues in patients with sporadic CRC.

Key words: Colorectal neoplasms. Alkylating agents. DNA repair. O(6)-methylguanine-DNA methyltransferase. Polymerase chain reaction.

\section{REFERÊNCIAS}

1. Wali RK, Skarosi S, Hart J, Zhang Y, Dolan ME, Moschel RC, et al. Inhibition of O(6)-methylguanine-DNA methyltransferase increases azoxymethane-induced colonic tumors in rats. Carcinogenesis. 1999;20(12):2355-60.

2. Zhong $Y$, Huang $Y$, Huang $Y$, Zhang $T$, Ma $C$, Zhang $S$, et al. Effects of O6-methylguanine-DNA methyltransferase (MGMT) polymorphisms on cancer: a meta-analysis. Mutagenesis. 2010;25(1):83-95

3. Herman JG, Umar A, Polyak K, Graff JR, Ahuja N, Issa JP, et al. Incidence and functional consequences of hMLH1 promoter hypermethylation in colorectal carcinoma. Proc Natl Acad Sci USA. 1998;95(12):6870-5.

4. Toyota M, Ahuja N, Ohe-Toyota M, Herman JG, Baylin SB, Issa JP. CpG island methylator phenotype in colorectal cancer. Proc Natl Acad Sci USA. 1999;96(15):8681-6.
5. Kondo N, Takahashi A, Ono K, Ohnishi T. DNA damage induced by alkylating agents and repair pathways. J Nucleic Acids. 2010:543531.

6. Baylin SB, Herman JG, Graff JR, Vertino PM, Issa JP. Alterations in DNA methylation: a fundamental aspect of neoplasia. Adv Cancer Res. 1998;72:141-96

7. Issa JP. CpG island methylator phenotype in cancer. Nat Rev Cancer. 2004;4(12):988-93.

8. Sabharwal A, Corrie PG, Midgley RS, Palmer C, Brady J, Mortimer $P$, et al. A phase I trial of lomeguatrib and irinotecan in metastatic colorectal cancer. Cancer Chemother Pharmacol. 2010;66(5):82935.

9. Shiraishi A, Sakumi K, Sekiguchi M. Increased susceptibility to chemotherapeutic alkylating agents of mice deficient in DNA repair methyltransferase. Carcinogenesis. 2000;21(10):1879-83.

10. Buckhaults $P$, Rago C, St Croix B, Romans KE, Saha S, Zhang L, et al. Secreted and cell surface genes expressed in benign and malignant colorectal tumors. Cancer Res. 2001;61(19):6996-7001. 
11. Ionov Y, Peinado MA, Malkhosyan S, Shibata D, Perucho M Ubiquitous somatic mutations in simple repeated sequences reveal a new mechanism for colonic carcinogenesis. Nature. 1993;363(6429):558-61.

12. Perucho M. Tumors with microsatellite instability: many mutations, targets and paradoxes. Oncogene. 2003;22(15):2223-5.

13. Jones PA, Baylin SB. The fundamental role of epigenetic events in cancer. Nat Rev Genet. 2002;3(6):415-28.

14. Wheeler JM, Beck NE, Kim HC, Tomlinson IP, Mortensen NJ, Bodmer WF. Mechanisms of inactivation of mismatch repair genes in human colorectal cancer cell lines: the predominant role of hMLH1. Proc Natl Acad Sci USA. 1999;96(18):10296-301.

15. Psofaki V, Kalogera C, Tzambouras N, Stephanou D, Tsianos E, Seferiadis K, et al. Promoter methylation status of hMLH1, MGMT, and CDKN2A/p16 in colorectal adenomas. World J Gastroenterol. 2010;16(28):3553-60.

16. Natarajan AT, Vermeulen S, Darroudi F, Valentine MB, Brent TP, Mitra $S$, et al. Chromosomal localization of human 06 methylguanine-DNA methyltransferase (MGMT) gene by in situ hybridization. Mutagenesis.1992;7(1):83-5.

17. Sakumi K, Shiraishi A, Shimizu S, Tsuzuki T, Ishikawa T, Sekiguchi M. Methylnitrosourea-induced tumorigenesis in MGMT gene knockout mice. Cancer Res. 1997;57(12):2415-8.

18. Sakai T, Toguchida J, Ohtani N, Yandell DW, Rapaport JM, Dryja TP. Allele-specific hypermethylation of the retinoblastoma tumorsuppressor gene. Am J Hum Genet. 1991;48(5):880-8.

19. Casorelli I, Russo MT, Bignami M. Role of mismatch repair and MGMT response to anticancer therapy. Anticancer Agents Med Chem. 2008;8(4):368-80.

20. Pegg $A E$, Byers TL. Repair of DNA containing O6-alkylguanine. FASEB J. 1992:6(6):2302-10.

21. Halford S, Rowan A, Sawyer I, Talbot I, Tomlinson I. O(6)methylguanine methyltransferase in colorectal cancers: detection of mutations, loss of expression, and weak association with $\mathrm{G}: \mathrm{C}>\mathrm{A}: \mathrm{T}$ transitions. Gut. 2005; 54(6);797-802.

22. Zaidi NH, Pretlow TP, O'Riordan MA, Dumenco LL, Allay E, Gerson SL. Transgenic expression of human MGMT protects against azoxymethane-induced aberrant crypt foci and $G$ to $A$ mutations in the K-ras oncogene of mouse colon. Carcinogenesis. 1995;16(3):451-6.

23. Qian XC, Brent TP. Methylation hot spots in the $5^{\prime}$ flanking region denote silencing of the 06-methylguanine-DNA methyltransferase gene. Cancer Res. 1997;57(17):3672-7.

24. Esteller M, Risques RA, Toyota M, Capella G, Moreno V, Peinado $M A$, et al. Promoter hypermethylation of the DNA repair gene $\mathrm{O}(6)$-methylguanine-DNA methyltransferase is associated with the presence of $\mathrm{G}: \mathrm{C}$ to $\mathrm{A}: \mathrm{T}$ transition mutations in p53 in human colorectal tumorigenisis. Cancer Res. 2001;61(12):4689-92.

25. Esteller M, Toyota M, Sanchez-Cespedes M, Capella G, Peinado MA, Watkins DN, et al. Inactivation of the DNA repair gene O6methylguanine-DNA methyltransferase by promoter hypermethylation is associated with $\mathrm{G}$ to $\mathrm{A}$ mutations in $\mathrm{K}$-ras in colorectal tumorigenisis. Cancer Res. 2000;60(9):2368-71.

26. Qi J, Zhu YQ, Huang MF, Yang D. Hypermethylation of CpG island in 06-methylguanine-DNA methyltransferase gene was associated with K-ras G to A mutation in colorectal tumor. World J Gastroenterol. 2005;11)13):2022-5.

27. Martinez CAR, Priolli DG, Cardinalli IA, Pereira JA, Portes AV, Margarido NF. Influência da localização do tumor na expressão tecidual da proteína p53 em doentes com câncer colorretal: estudo de 100 casos. Rev Col Bras Cir. 2008;35(4):235-43.

28. Sanchez de Abajo A, de la Hoya M, van Puijenbroek M, Godino J, Díaz-Rubio E, Morreau H, et al. Dual role of $\mathrm{LOH}$ at MMR loci in hereditary non-polyposis colorectal cancer ? Oncogene. 2006;25(14):2124-30.

29. Martinez CAR, Cordeiro AT, Priolli DG, Miranda DDC, Bartchewsky Júnior W, Margarido NF, et al. Avaliação da expressão tecidual do gene de reparo MLH1 e dos níveis de dano oxidativo ao DNA em doentes com câncer colorretal. Rev bras colo-proctol. 2009:29(3):303-13.

30. Park JH, Kim NS, Park JY, Chae YS, Kim JG, Sohn SK, et al. MGMT $-535 \mathrm{G}>\mathrm{T}$ polymorphism is associated with prognosis for patients with metastatic colorectal cancer treated with oxaliplatin-based chemotherapy. J Cancer Res Clin Oncol. 2010;136(8):1135-42.

Recebido em 18/05/2011

Aceito para publicação em 20/07/2011

Conflito de interesse: nenhum

Fonte de financiamento: Fundação de Amparo a Pesquisa do Estado de São Paulo. (Processo n 2008-51499-7).

\section{Como citar este artigo:}

Cordeiro AT, Silva CMG, Bartchewsky Júnior W, Ribeiro ML, Martinez CAR. Avaliação da expressão do gene MGMT nos tecidos normal e neoplásico de doentes com câncer colorretal. Rev Col Bras Cir. [periódico na Internet] 2012; 39(1). Disponível em URL: http://www.scielo.br/ $\mathrm{rcbc}$

\section{Endereço para correspondência:}

Carlos Augusto Real Martinez

E-mail: caomartinez@uol.com.br 